\title{
A Survey on Karen Tuttle's Coordination: considerations of legacy, dissemination, and notation.
}

\author{
(iD) Leonardo Piermartiri \\ Universidade do Estado de Santa Catarina, Florianópolis, Santa Catarina, Brasil \\ leonardo.piermartiri@udesc.br \\ iD Daphne Capparelli Gerling \\ University of North Texas, Denton, Texas, EUA \\ daphne.gerling@unt.edu
}

\begin{abstract}
Violist and pedagogue Karen Tuttle developed through her own personal experience, a series of techniques and teaching principles that later came to be known as "Coordination." By observing preeminent musicians in action over many years, she decodified the movements necessary to perform viola in a fluid and natural way and was able to transmit these teachings to her students. Tuttle left behind few written resources regarding Coordination, and never established a formal method for conveying her techniques. The information we have today has been transmitted through her students, many of whom now hold positions as professors in leading music schools and conservatories throughout the United States and abroad. The purpose of this study is to gather and analyze data from the viola community that shows how violists have been using, practicing, notating and teaching Coordination.
\end{abstract}

Keywords: Karen Tuttle's Coordination. Viola Performance. Body awareness techniques for violists. Survey on musician's practices.

Resumo: A violista e pedagoga Karen Tuttle desenvolveu através de sua própria vivência uma serie de técnicas que foram chamadas de Coordination. Através da observação da atuação de músicos proeminentes, ela decodificou os movimentos necessários para alcançar uma maneira de tocar a viola mais fluida e natural, e foi capaz de transmitir isso para os alunos. Tuttle deixou poucos documentos escritos sobre Coordination, 
e nunca estabeleceu uma formatação definitiva para a notação dessas técnicas. As informações remanescentes têm sido transmitidas pelos seus alunos, muitos dos quais são professores nas principais universidades e conservatórios dos Estados Unidos e de outros países. O objetivo deste estudo é de coletar e analisar informações provenientes da comunidade de violistas que mostra como eles tem usado, estudado, escrito e ensinado Coordination.

Palavras-chave: Coordination de Karen Tuttle. Performance na viola. Conscientização corporal para violistas. Questionário de práticas musicais.

Submetido em: 30 de novembro de 2020

Aceito em: 5 de janeiro de 2021 
A Survey on Karen Tuttle's Coordination: considerations of legacy, dissemination... Leonardo Piermartiri • Daphne Capparelli Gerling

\section{Introduction}

Karen Tuttle was a renowned violist and pedagogue, professionally active in the United States and internationally from the mid-twentieth century until her passing in 2010. She developed her techniques now known as "Coordination" over the span of her five-decade long career, becoming one of the most well-known viola professors in the United States. Her approach to teaching has proven to be a very effective way of providing violists with tools to develop a connection between the physical and the emotional aspects of their playing in order to better project their musical ideas. Tuttle never intended to establish an ultimate "method," and was not inclined to the idea of setting these techniques into a print format or teaching them in a standardized way. Therefore, the information we have these days has been transmitted through at least two generations of her students who are now prominent performers and professors in major institutions throughout the United States and abroad.

Tuttle had a personal teaching style based on respect and love for the student. Her approach to teaching Coordination was individualized, taking in the vast diversity of students' physique, experience, and needs. Her success is attested through her students' writings and testimonials. Most recently, the publication of the book The Karen Tuttle Legacy in March 2020 brought together the most detailed account of Tuttle's teaching related by six of her most prominent students. Each chapter addresses a technical aspect of her teaching through each author's perspective. Even though they describe that her approach with each of them was different, the goal was all the same: to acquire a beautiful deep sound, and freedom of movement and expression, all according to the musical phrase. 
A Survey on Karen Tuttle's Coordination: considerations of legacy, dissemination... Leonardo Piermartiri • Daphne Capparelli Gerling

\section{Previous Research and Notation}

The subject of Coordination in published studies is recent and has not been exhaustively discussed academically. In addition to the few articles and interviews published when Karen Tuttle was still alive (DEW 1993), RODLAND (2004), some works have been published investigating different aspects of her Coordination techniques. Dane's dissertation (2002) discusses in depth the early years and diffusion of Tuttle's Coordination and her legacy being carried on by her former students.

Other dissertations focus on comparing Coordination with other techniques such as the approach of the violin pedagogue Paul Roland (BURNS 2013), and Body Mapping and Alexander Technique (NAPIER 2019).

The work of Reiter (2008) registers and documents the different Coordination techniques explained directly from Tuttle in her last years of life. The book is accompanied by a video recording of an interview Tuttle gave to one of her most preeminent students, Kim Kashkashian, followed by a session where the author plays the viola and receives instruction from Tuttle. Regarding notation, the book only gives three short musical examples, on pages 38 and 67 with three symbols, R for Repull, " $\sim s$ " Over-the-bow, and "I" for groupings, but does not present any further explanation. In another section of the book, Reiter presents the symbol " $\sim$ " explaining the technique for what Tuttle called "scooping the sound."

Tuttle's comment to the final work reveals her approach to Coordination and what she considered most important: a work that is meaningful and adaptable to different people.

What impresses me is that you include current variations on the technique, indicating that it is flexible enough to vary with the style and physique of the performers. I am also glad that it is not simply a cold, technical work, but that it has personality and heart" (Reiter, 2008:74). 
A Survey on Karen Tuttle's Coordination: considerations of legacy, dissemination... Leonardo Piermartiri • Daphne Capparelli Gerling

Sander's dissertation (2013) reiterates the fact that Tuttle never published a notational system for Coordination. To notate the gestures on the score, Sander uses markings collected from both Tuttle's and her former students' scores.

According to Sander (2013, p.6-7)

Several of Tuttle's students have acknowledged that they used score markings to indicate where to apply each aspect of Coordination. Susan Dubois described the markings in her music and stated that they "[look] like a roadmap - marks for the neck release, arrows for phrase direction, roller-coaster curves going to or through notes, and undulating mountains and valleys to remind me to fill up notes."

Inspired by that practice, Sander created a comprehensive educational guide to the motions of Coordination, preserving its authenticity for future generations of students and opening its study to a much broader population. She notated a suggested interpretation of the entire first movement of Bloch's Suite Hébraïque, using four gestures called: downward motion, upward motion, neck release, and repull.

The aforementioned book The Karen Tuttle Legacy is probably the most complete written source for Coordination. However, it does not focus on the notational aspect of it, presenting only three musical scores by Kashkashian (IRVINE, 2020, p. 92) with two gestures: repull and over the bow.

Although the notation of Coordination gestures per se doesn't mean much if the performer doesn't know how to execute them, it is an important means of registering and transmitting this knowledge. A comparison of these sources led to our discussion regarding differences in notation and the need to investigate current notational practice by violists and its many possible variations.

Of the notational symbols contained in the above-mentioned bibliography we chose the following ones to be part of the survey: 
A Survey on Karen Tuttle's Coordination: considerations of legacy, dissemination... Leonardo Piermartiri • Daphne Capparelli Gerling

- Re-pull “R” (REITER, 2008, p. 38) and (SANDER, 2013, p. 31)

- Neck release "N" (SANDER, 2013, p. 31)

- Over-the bow $\sim$ (REITER, 2008, p. 38)

- Grouping $=$ (REITER, 2008, p. 38)

- Scooping the sound $ح$ (REITER, 2008, p. 38)

- The Downward Gesture: (Tuttle manuscript)

- The Upward Gesture: (IRVINE et al, 2020, p.110)

The present study intends to investigate the impact of Tuttle's ideas and teaching in the viola community and how important and useful they have become by examining to what extent Coordination is known, how it has affected violists' experiences, and to assess what forms of notation are currently being used.

\section{Method}

We developed an online survey to gather both quantitative and qualitative information giving it a mixed-method design. The survey had a completion time of approximately 8 minutes and was divided into 3 sections with a total of 20 closed-ended questions and 5 optional open-ended questions. The open-ended questions were spread within the sections allowing participants to give detailed answers about their experience with Coordination in the different topics. The data collected in the closed-ended questions was analyzed quantitatively, while the open-ended questions added information of interest for a qualitative analysis allowing 
A Survey on Karen Tuttle's Coordination: considerations of legacy, dissemination... Leonardo Piermartiri • Daphne Capparelli Gerling

for a richer interpretation of the data. Answering each question was optional. The survey was created using Google Forms, and the resulting data organized using graphics and a spreadsheet.

Participants were recruited from a population of violists in the Facebook social media groups Facebook Violists and the International Viola Society. In addition to those groups, we sent emails to 32 viola professors from major universities in the United States. The link to the survey was included in these emails, thus making it possible for further distribution by the subjects. Subjects consented to participate using an approved IRB protocol from the University of North Texas. The survey collected responses within a two-month window between the months of August and October 2020.

\section{Results}

\section{Demographics}

A total of 100 people completed the survey. From this total, the majority were from the United States (58.5\%), with a representation of 25 different states, and $41.5 \%$ were from 16 other countries. The first question asked about the participant's primary instrument was answered by 99 participants, of which $90.9 \%$ answered viola and $9.1 \%$ violin.

Concerning the occupation, 100 participants answered a multiple-choice question, being $64 \%$ professional performers, $37 \%$ teachers, 33\% professors, $15 \%$ graduate students, $7 \%$ amateurs and $6 \%$ undergraduate students. (Fig. 1A)

84 subjects answered about the level they teach primarily. The majority (50\%) teach advanced or college level, $22.6 \%$ teach intermediate, $21.4 \%$ teach beginners, and $6 \%$ teach $\mathrm{K}-12$ string groups or school orchestra. (Fig. 1B) 
A Survey on Karen Tuttle's Coordination: considerations of legacy, dissemination... Leonardo Piermartiri • Daphne Capparelli Gerling

\section{Figure 1. Demographics}

A

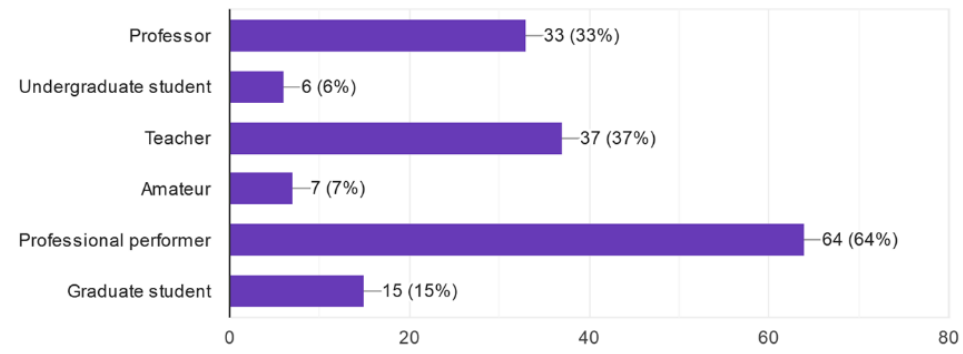
C
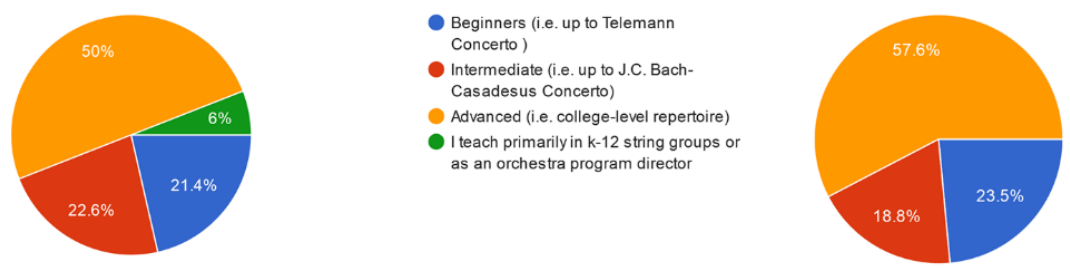

1 to 5 years 5 to 10 years (marily in $\mathrm{k}-12$ string groups or

Concerning the amount of time, they have been teaching, most of them (57.6\%) answered more than 10 years, $18.8 \%$ from 5 to 10 years, and 23.5\% from 1 to 5 years. (Fig. 1C)

\section{Knowledge of and experience with Coordination}

The second section was about knowledge of Coordination, and the first question asked if the subject is familiar with Karen Tuttle's Coordination techniques. Of the 100 responses, 61\% answered "yes," and 39\% answered "no." To those that answered negative, there was a suggestion to submit the survey at that point and end it without answering the remaining questions. ${ }^{1}$

When asked how well they know the Coordination techniques, the answers resulted roughly one-third for each option: $37.9 \%$ moderately, 33.3\% vaguely, 28.8\% deeply, out of a total of 67. (Fig. 2A)

The great majority of participants $57.8 \%$ answered that they teach some general concepts of Coordination to their students; $26.6 \%$ do not teach Coordination; $15.6 \%$ answered that Coordination is integral to how they teach. (Fig. 2B)

1 There were 6 participants that answered that they were not familiar with Coordination techniques but continued the survey to the end. Their answers were not excluded. 
A Survey on Karen Tuttle's Coordination: considerations of legacy, dissemination... Leonardo Piermartiri • Daphne Capparelli Gerling

We wanted to know also by what means the participants had first become acquainted with Coordination, so we posed a multiple-choice question. Most of the participants (68.7\%) chose "Conversations with colleagues and peers" followed by "Literature" (50.7\%). Also, 41.8\% mentioned having studied with one or more of Karen Tuttle students; $29.9 \%$ attended a Coordination Seminar; $16.4 \%$ studied directly with Tuttle. (Fig. 2C)

\section{Figure 2. Awareness of Coordination}
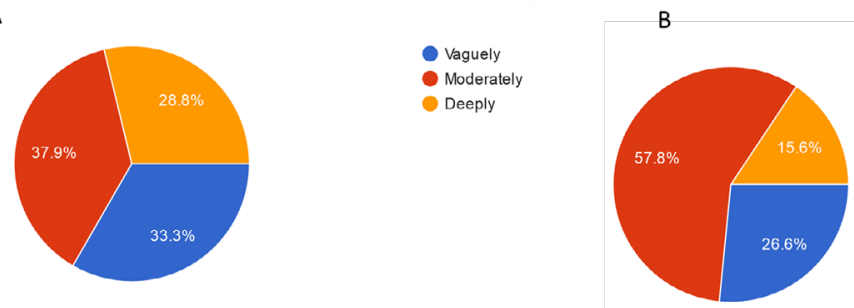

C

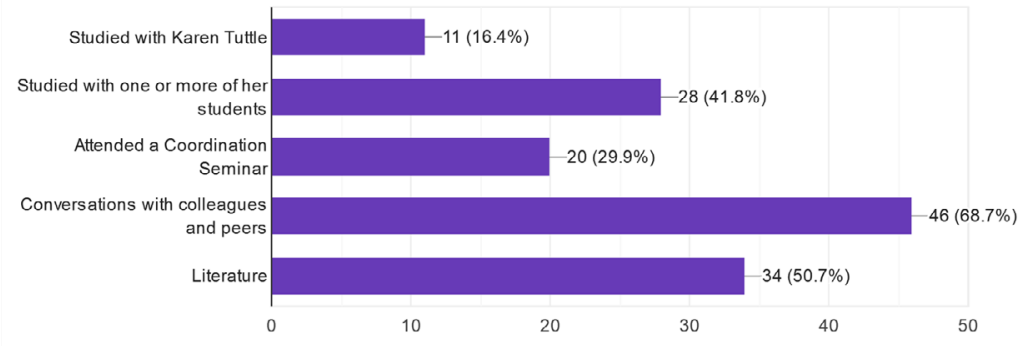

In the question about how frequently they think or practice these techniques themselves, $41.9 \%$ chose the option that they practice it, but are not always conscious of how or when they are using it; $22.6 \%$ marked "always;" 19.4\% know the techniques but struggle to use them consistently; $9.7 \%$ said they employ them consciously only when starting a new piece; $6.5 \%$ only when struggling with a passage. (Fig. 3A)

The overwhelming majority, $84.6 \%$ out of 65 responses, selected to respond that it was worth the effort to go through the challenges of learning Coordination, whereas $13.8 \%$ stated that they were indifferent to it. (Fig. 3B) 
A Survey on Karen Tuttle's Coordination: considerations of legacy, dissemination... Leonardo Piermartiri • Daphne Capparelli Gerling

Of the 62 responses regarding whether Coordination has helped overcome pain or injuries from playing, 67.7\% answered "yes," and 32.3\% chose "no." (Fig. 3C) Following that, the next question asked if the recovery was a combination of Coordination and medical treatment. Of 48 responses, 70.8\% said "no," and $29.2 \%$ said "yes."

$44.8 \%$ out of 67 participants believe applying Coordination to their playing is essential, and $40.3 \%$ think it is interesting but not essential. (Fig. 3D)

Figure 3. Use of Coordination

A

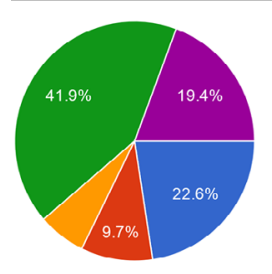

C

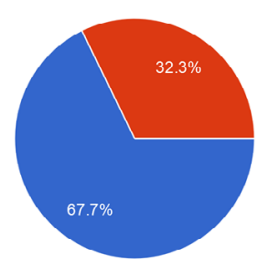

B

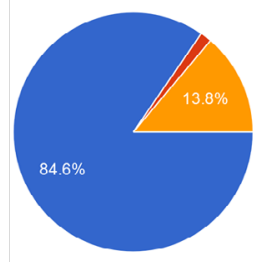

Yes

Indifferent

when proach

when playing, at all phases of learning
and performing.

Only when starting a new piece. Once it

is second-nature, I don't consciously...

Only when I struggle with a passage.

I practice it, but I'm not always

I know the techniques, but I struggle to

use them consistently in my playing.

D

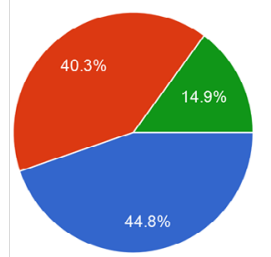

Essential

Interesting but not essential Irrelevant

The open-ended question in this section was about other musical/technical approaches that significantly inform their playing or teaching. From a pool of 29 written responses, other approaches and techniques were mentioned as follows: Alexander Technique, 8 responses; Yoga, 7 responses; Body mapping, 5 responses; Feldenkrais, 4 responses; Kato Havas, 3 responses; Paul Rolland, 3 responses. 
A Survey on Karen Tuttle's Coordination: considerations of legacy, dissemination... Leonardo Piermartiri • Daphne Capparelli Gerling

\section{Notation}

The third section focused on the awareness and use of notation for the different Coordination techniques found in the existing literature. Of 68 responses, $17.6 \%$ answered "yes"; $63.2 \%$ do not use any notation to indicate Coordination techniques; $19.1 \%$ use it sometimes. (Fig. 4A)

We chose to present seven different notational symbols to assess how well-known they are among the group that knows Coordination and notates it in practice. Of the 45 responses received, the most well-known notational symbols are: Neck Release (73.3\%), Repull (68.9\%), Downward Gesture (51.1\%), Grouping (48.9\%), Scooping the Sound (42.2\%), Upward Gesture (42.2\%), and Over-the-Bow (37.8\%). (Fig. 4B)

Of a total of 28 responses, the symbols most frequently marked in their parts are Neck Release (50\%), Downward Gesture (46.4\%), Grouping (42.9\%), Repull (28.6\%), Upward Gesture (28.6\%), Overthe-Bow (25\%) Scooping the Sound (10.7\%). (Fig. 4C)

When asked if they mark the part of the body used for certain passages, out of 65 responses, $60 \%$ answered negatively; $21.5 \%$ answered sometimes; $18.5 \%$ answered positively. (Fig. 4D)

When asked if they actively think of Tuttle's emotions list while preparing and performing a piece, 37.3\% answered "yes;' 35.8\% answered "sometimes;" 26.9\% answered "no" out of 67 responses. (Fig. 5A)

When asked if they mark the emotions in their scores, 37.3\% answered "no;' 34.3\% answered "sometimes;" 28.4\% answered "yes" out of 67 responses. (Fig. 5B) 
A Survey on Karen Tuttle's Coordination: considerations of legacy, dissemination... Leonardo Piermartiri • Daphne Capparelli Gerling

\section{Figure 4: Notation}

A

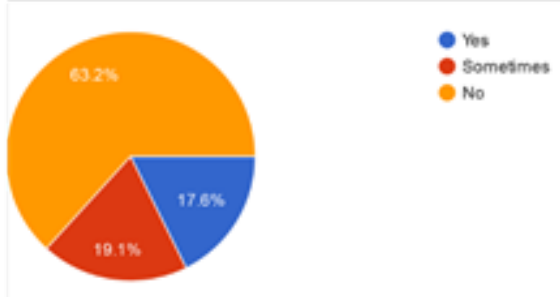

C
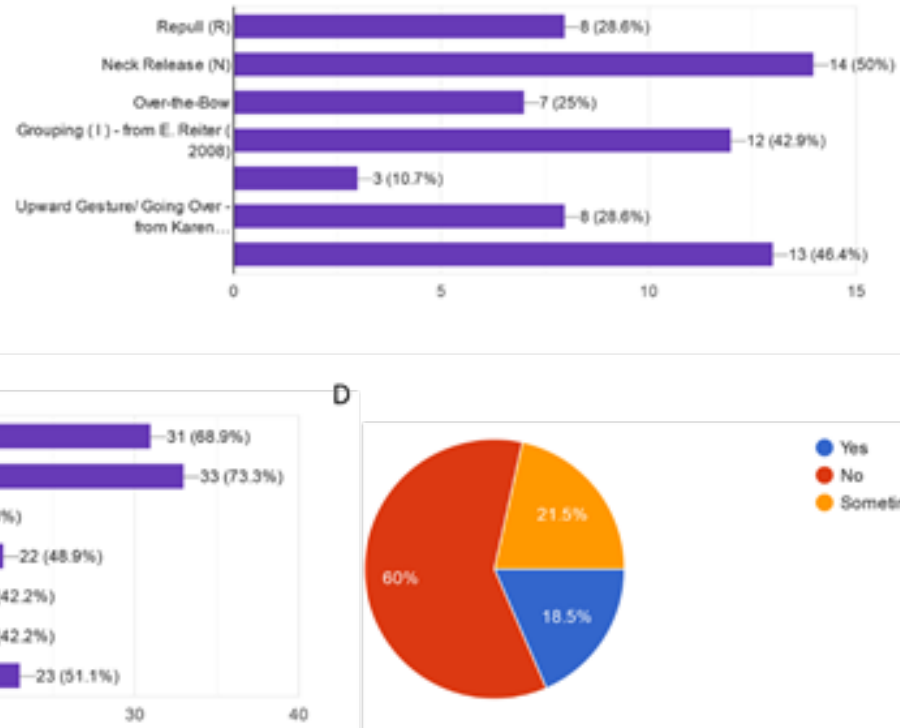

- Yes

- Somesmes
D

Figure 5: Tuttle emotions

A

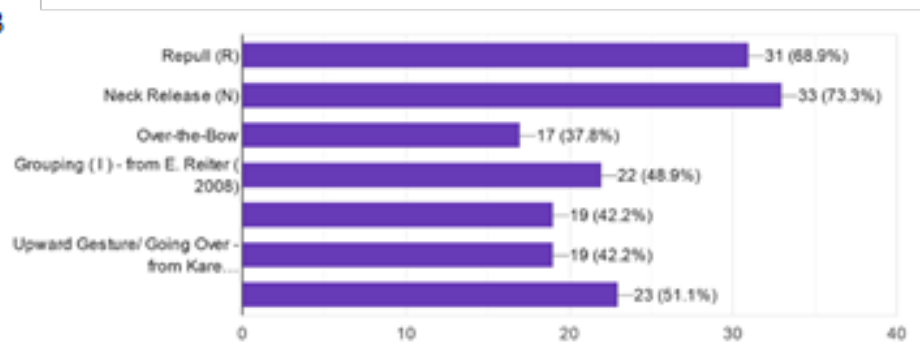

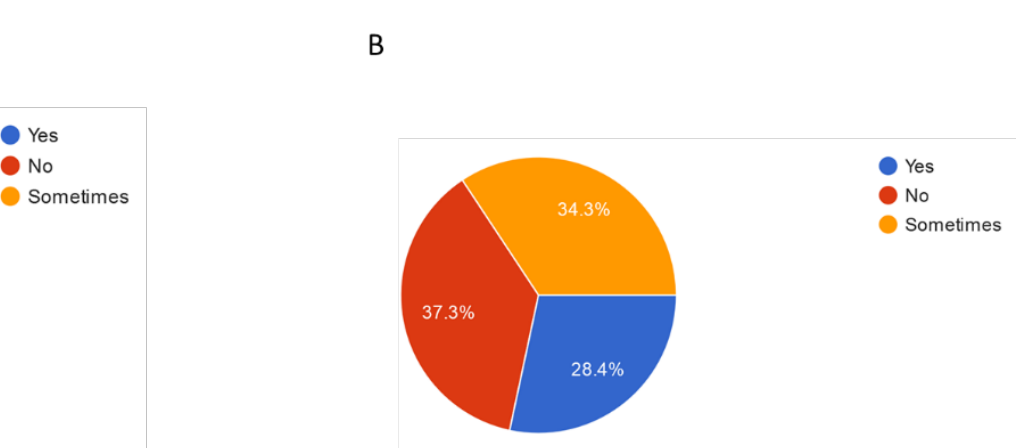

\section{Discussion}

Results showed that out of 67 participants that are familiar with Coordination, 11 studied directly with Tuttle, and 28 studied with her students, making it 39 people (58.2\%) that have experienced these techniques from a primary and/or secondary source. Among this group of $67,44.8 \%$ indicated that Coordination is essential in their approach to playing. 
A Survey on Karen Tuttle's Coordination: considerations of legacy, dissemination... Leonardo Piermartiri • Daphne Capparelli Gerling

Within this group, 11 participants studied with Tuttle, with 6 of them stating they believe that applying Coordination to their playing is "essential" and 5 stating they believe that it is "interesting but not essential."

The great majority (84.6\%) said that the challenges of learning Coordination are worth the effort. Participants' testimonials confirm Coordination's efficacy in helping a performer obtain a pain-free playing life: "Coordination supplemented my use of the Alexander Technique." (Participant n. 16); "Body Mapping along with Tuttle Coordination has really helped my injuries. (Participant n. 21); "Coordination brings more body awareness. Consequently, less effort and hardness." (Participant n. 33)

Also, the following comments validate that Coordination helps violists develop awareness of tension and release in their own body:

Before learning from a Tuttle perspective, I had immense pain in my left shoulder and was always very tense while performing. After practicing Coordination for the past three years, I hardly have any tension at all and am able to stay calmer and more centered while performing and practicing. (Participant n. 28)

Having Coordination as an intent guided my awareness as I rebuilt my technique after 18 months away from the viola (overuse issues from orchestral playing). (Participant n. 85)

I started to feel neck pains, so I remembered the importance of the neck to be free and following the "opening" movement of the down bow, and the neck-roll over the chin rest. (Participant n. 18)

...exposure to Coordination has made me more aware of what my body is doing and how I am breathing when I am playing, especially in terms of the position of the shoulders, and I

2 Of the 11, one mentioned knowing Coordination vaguely and clarified it by writing that this participant had studied with KT only in two Summer festivals and therefore does not consider it essential. 
A Survey on Karen Tuttle's Coordination: considerations of legacy, dissemination... Leonardo Piermartiri • Daphne Capparelli Gerling

think this has helped my playing and teaching tremendously (Participant n. 93).

Findings from this study showed that most participants (63.2\%) don't write any kind of notation to indicate Coordination. Further, when asked if they mark the emotions they want to portray, that number drops to $37.3 \%$. This indicates that musicians are more likely to write down the emotional characters they want to convey in the piece than to notate other technical concepts that need to be internalized. One comment explains this:

Concepts such as neck release, to me, should not have to be visual reminders on a page -- and if you need constant visual reminders to play a certain way, one is not truly learning how to connect the brain with the body motion. Coordinated action is not a specific list of things to do or achieve. It would start to emerge as the natural way to make a sound with distinct character and intent (Participant n. 82).

On the other hand, the following comment connects the physical with the musical ideas: "I suppose I use some markings as phrase gestures (indicating musical ideas, as opposed to a reminder of something physical) - which I suppose end up signaling something physical!" (Participant n. 85).

Some comments also reinforce the idea that when one incorporates Coordination at a deeper level it may no longer be manifested consciously: "at this point it operates in the background 99 percent of the time;" "When you've done something so long that it is second nature, you're not aware of doing it or not" (Participant 71).

Concerning the familiarity of the participants with the symbols found in the literature, none of the notational symbols we selected for the survey was universally known by all respondents. That fact confirms that notation has not received standardized attention.

Both questions about Tuttle's emotions list have a strong number of participants saying that they use it. When excluding the 
A Survey on Karen Tuttle's Coordination: considerations of legacy, dissemination... Leonardo Piermartiri • Daphne Capparelli Gerling

ones that don't actively think of it, the percentage is $73.1 \%$, and for those who mark the emotion in their parts the percentage is $62.7 \%$. This suggests that the emotions list is an important tool for performers, with roughly $2 / 3$ using it in some form. The following are some of the testimonials about Tuttle's emotions list: "The Five Basic Emotions list is so powerful and essential to my teaching; I've translated the list into Bahasa Indonesian for my students in Jakarta and Bandung" (Participant n. 9); "I received the emotions list way back in the day from Heidi and Vicky at Aspen and have used it for years in my teaching. I integrate it into my Pedagogical vibrato technique tool" (Participant n. 77); "YES!! Always referencing her Emotions List as a guide to making informed physical, technical choices" (Participant n. 79).

As mentioned previously, not all Tuttle students had the same experience and were exposed to the same techniques the same way. The following testimonials attest to the idea that even a partial knowledge of Tuttle's concepts significantly impacted several respondents:

Since I have only been exposed to these ideas in seminars and casual conversations with colleagues, I only apply what I feel I can understand without having received one-on-one instruction on the subject. These are mainly left-hand ideas. The bow repull/right hand ideas, I don't feel I understand well enough (Participant n. 93).

I'm still working on using the techniques consistently. I focus on them more in passages that I'm struggling on, but after I'm finished intensely practicing a section, the techniques fall to the wayside a bit unless I write something in my music to remind myself (Participant n. 24).

In my opinion, Coordination is one of the greatest tools that we can add to our body perception while playing the instrument. It improves the results at about any direction, especially for 
A Survey on Karen Tuttle's Coordination: considerations of legacy, dissemination... Leonardo Piermartiri • Daphne Capparelli Gerling

sound production. I realize when students have an easy way of living life, Coordination principles are more natural for them to incorporate. For this reason, the process of encouraging selfknowledge is very important to me (Participant n. 33).

Tuttle evolved during her career and developed different ways to convey her ideas (IRVINE et al, 2020, p. 5). These testimonials from participant n. 100 in the open-ended questions corroborate that: "I studied with Karen for $5+$ years. I was never aware that she ever had a "system," per se. It is interesting to see how differently people remember her teaching. I loved Karen, and she changed my life;" and also: "I don't remember Karen using most of these markings, and I don't believe she kept any kind of set list".

We suggest that the use of these notations can be helpful for the performer and also help create greater awareness of the different applications of Coordination. While notational symbols will continue to appear in a variety of forms, their inclusion in editions and scholarly materials suitable for presentation to students would contribute to making these techniques more interesting and accessible. However, it cannot be overstated that the use of these symbols in a vacuum would not suffice to give a player a deep knowledge of these principles. We encourage all violists or other musicians interested in learning more about Coordination to contact a teacher from this lineage, to attend the Tuttle Coordination Seminars online or in person, and to seek out video resources such as those created by Carol Rodland. As with the advanced study of all art forms, merely having access to printed documents or recorded media will never fully substitute for live interaction and guidance by an experienced master teacher who has a lifetime of experience. 
A Survey on Karen Tuttle's Coordination: considerations of legacy, dissemination... Leonardo Piermartiri • Daphne Capparelli Gerling

\section{Referências}

BURNS, Lauren. Coordinated action in string playing: a comparative study of the teaching of Paul Roland and Karen Tuttle. Doctoral dissertation. Tuscaloosa: The University of Alabama, 2013. 101p.

DANE, Matthew. Coordinated Effort: A Study of Karen Tuttle's Influence on Modern Viola Teaching. Doctoral dissertation. Houston: Rice University, 2002. 65p.

DEW, Robert. In Response to Instinct - Karen Tuttle's Insights into the Coordinated Action - its Mechanisms, Articulation, and Prerequisites. The Strad, 104, no. 1241, p. 835-838, September 1993.

IRVINE, Jeffrey; KASHKASHIAN, Kim; LACOURSE, Michelle; RAMSEY, Lynne; RITSCHER, Karen; RODLAND, Carol. The Karen Tuttle Legacy: A Resource and Guide for Viola Students, teachers, and Performers. New York: Carl Fischer, 2020. 176p.

NAPIER, Erin. Fostering Freedom: A Holistic Comparison of Karen Tuttle's Ideas with Body Mapping and the Alexander Technique. Doctoral dissertation. Boulder: University of Colorado, 2019. 66p.

REITER, Emmanuella. Karen Tuttle's Heritage: the theory and practice of co-ordination. Boston: Allegra Print \& Imaging, 2008. 77p.

RODLAND, Carol. Master Class: In Honor of Karen Tuttle as She Retires. American String Teacher, 54, n.2, p. 45-47, May 2004.

SANDER, Amber. Performer's Guide to the Execution and Application of Karen Tuttle's Coordination, as Applied to Ernest Bloch's Suite Hébraïque. Doctoral dissertation. Denton: University of North Texas, 2013. 62p.

\section{Aprovação de comitê de ética em pesquisa}

Aprovado pelo Institutional Review Board of University of North Texas. 
A Survey on Karen Tuttle's Coordination: considerations of legacy, dissemination... Leonardo Piermartiri • Daphne Capparelli Gerling

\section{Publisher}

Universidade Federal de Goiás. Escola de Música e Artes Cênicas. Programa de Pós-graduação em Música. Publicação no Portal de Periódicos UFG.

As ideias expressadas neste artigo são de responsabilidade de seus autores, não representando, necessariamente, a opinião dos editores ou da universidade. 